\title{
DIVERSITY IN TYPHOID DIAGNOSTIC PROTOCOLS AND RECOMMENDATION \\ FOR COMPOSITE REFERENCE STANDARD
}

\author{
Bernard Egwu Igiri a,*, Stanley Irobekhian Reuben Okoduwa a,b,\#, Shaibu Ahmed Munirat ${ }^{\mathrm{c}}$, \\ Iquo Bassey Otu-Bassey ${ }^{\mathrm{d}}$, Abdullahi Bashir, ${ }^{\mathrm{c}}$, Otori Mercy Onyiyioza ${ }^{\mathrm{c}}$ \\ ${ }^{a}$ Directorate of Research and Development, Nigerian Institute of Leather and Science \\ Technology, Zaria, Nigeria \\ ${ }^{\mathrm{b}}$ Department of Biochemistry, Babcock University, Ilishan-Remo, Nigeria \\ ${ }^{c}$ Department of Microbiology, Ahmadu Bello University, Zaria, Kaduna State, Nigeria \\ ${ }^{\mathrm{d}}$ Department of Medical Laboratory Sciences, University of Calabar, Calabar \\ *Correspondence: B.E. Igiri, Medical Microbiologist/Parasitologist, \\ egwubernard2@gmail.com; Tel.: +234-706-859-7797 \\ \# Co-Correspondence: Dr. S.I.R. Okoduwa, Medical Biochemist/Toxicologist, Department of \\ Biochemistry, School of Basic Medical Sciences, Babcock University, Ilishan-Remo, Nigeria. \\ okoduwas@babcock.edu.ng, siroplc@gmail.com, Tel: +234-803-295-5882
}

\begin{abstract}
Typhoid fever is a major public health burden which causes substantial global morbidity and mortality due to lack of decisive diagnostic protocols. The capacity of commonly use diagnostic test to validate the absence of typhoid fever is controversial. This study explores to evaluate new techniques for typhoid diagnosis and proposed a harmonised suitable standardized composite reference to be adopted. Published peer-reviewed articles indexed in PubMed, MEDLINE and Google scholar were reviewed for hospital-based studies. This study reveals new typhoid diagnostic techniques such as proteomics, serology, Rapid Diagnostic tests (RDTs), transcriptomics, genomics, and metabolomics. $34.4 \%$ of the studies use prospective study design. The study result establishes that, Widal test has a moderate diagnostic accuracy with average percentage sensitivity $(52.9 \%)$, specificity (54\%), positive predictive value (PPV) $(56.8 \%)$ as well as negative predictive value (NPV) (55.6\%) when compared with $29.4 \%, 28 \%, 29.5 \%$, and $27.8 \%$ of Typhidot respectively. The findings showed a statistically significant difference on the
\end{abstract}


sensitivity between Widal and Typhidot $\mathrm{t}(40)=2.639, p=0.012$ at $p<0.05$ using independent sample $t$-test. When there is no perfect reference standard that has an optimal diagnostic accuracy, the need for a harmonised suitable standardized composite reference is essential. Hence, this study recommends that, peripheral blood culture with established sensitivity of $60 \%$ and Widal test with average sensitivity of $52.9 \%$ be adopted as a consensus composite reference standard for typhoid fever diagnosis in other to improve confidence in prevalence estimates.

Keywords: Typhoid fever; Diagnostic; Metabolomics; Composite reference standard; Accuracy; Sensitivity.

\section{INTRODUCTION}

Enteric fever (EF), commonly called typhoid fever (TF) is a systemic infectious disease caused by Salmonella Typhi and Salmonella Paratyphi, which if left untreated could cause substantial ill health and death. The disease causes serious public health challenge, with approximately 12,000,000 to 27,000,000 cases annually (Kumar et al., 2005; Alba et al., 2016). The estimated death varies between 129,000 to 223,000 annually (WHO 2015; Stanaway et al., 2019). Typhoid fever causes overwhelming affliction in low and middle income countries, with a world-wide projection of 11.9 million cases and 120 000-220 000 mortality yearly (Buckle et al., 2012; Mogasale et al., 2014). The prevalence of TF has been reported to be high in preschool children and infants (Crump et al., 2004; Crump et al., 2008; Mogasale et al., 2014; Britto et al., 2017). In Africa, it has been observed that the burden of the disease is significantly high (Mogasale et al., 2014; Antillón et al., 2017).

Lack of suitable diagnostic test as well as effective antibiotic treatment could result in TF death (Dutta et al., 2014). In perspective to the absence of decisive diagnostic protocols, the disease 
could lead to fatal complications such as intestinal perforations (Haques et al., 1999). Research findings for the best enteric fever diagnostic techniques are being carried out by many research groups globally, with elusive results (Baker et al 2010). The diagnostic accuracy of typhoid fever is a major challenge. The gap in TF diagnosis has led to under-diagnosis, imprecise disease burden estimates, inaccurate, and over-diagnosis that could result in inappropriate and excessive intake of antibiotics (Wlekidan et al., 2015; Igiri et al., 2018). Various diagnostic techniques have been employed, including blood and bone marrow culture that were recommended as reference standard diagnostic tests (Vallenas et al., 1985; WHO 2003). The most sensitive and specific test for enteric fever is bone marrow culture, though, invasive with medical complications, requiring technical expertise and specialized equipment (Mogasale et al., 2016).. Blood culture is the most frequently used techniques among culture based methods with limited resources for proper culturing in many setting (Storey et al., 2015). Blood and bone marrow culture sensitivity has been quantified at 40$80 \%$ and $>80 \%$ respectively (Storey et al., 2015; Mogasale et al., 2016).

Rapid and accurate enteric fever diagnosis is significant and could reduce mortality, ill health and control the spread of the ailment (Zaki and Karande 2011; Ugochukwu et al.,2013; Goay et al., 2016; Sandro 2017). Widal test is widely used due to its readily availability and affordability, but lack sensitivity and specificity and is not very reliable (Parry et al 2011; Andrews and Ryan 2015; Maude et al 2015; Darton et al 2017). However, this cheap and quick Widal test is the reason for the extensive report on the incidence of typhoid fever in different areas of Nigeria (Igiri et al., 2018). Novel diagnostic techniques for enteric fever are in progress that could mitigate this deficit. New point-of-care technologies such as rapid magneto-DNA nanoparticle assay, proteomics, genomics, Loop Mediated Isothermal Amplification, Typhidot, Polymerase Chain Reaction (PCR), transcriptomic, and metabolomic has been establish (Kantele et al., 2013; Charles et al., 2014; Darton et al., 2015; Park et al., 2016; Blohmke et al., 2016; Darton et al., 2017; Sharma et 
al., 2018). Hemagglutination and enzyme linked immunosorbent assay (ELISA) are serological tests used for Salmonella enterica serova Typhi $\mathrm{H}$ and $\mathrm{O}$ antigens with poor sensitivity and specificity (Lateef et al., 2000).

. The use of gold standard test with imperfect diagnostic accuracy could bring about newer and better technique (Whiting et al., 2013). The development of a composite reference standard (CRS) is alternative technique to improve diagnostic accuracy in the absence of a perfect reference test (Alonzo and Pepe 1999). Composite reference standard is the combination of more than one imperfect technique aimed at increasing diagnostic accuracy. This study discussed current biomarkers of enteric fever diagnosis and presented the diagnostic performance of typhoid fever test. However, based on the results of these findings, the study proposed a harmonised CRS for adoption as suitable standardized composite reference which would help to improved confidence in the prevalence estimates of typhoid fever infections.

\section{NEW BIOMARKERS OF ENTERIC FEVER DIAGNOSIS}

\subsection{Proteomics}

Serological markers that are available for enteric fever test are characterized with low sensitivity and specificity. In Nigeria, studies on children with acute enteric fever based on proteome microarray tested IgA, IgM and IgG ELISAs using S. Typhi LPS and hemolysin E (HlyE) proteins (Huw et al., 2016; Felgner et al., 2017). This study recognized putative sero-diagnostic biomarkers such as invasion (SipC), proteins targeted toward host cell attack (HlyE) and bacterial cell surface (OmpA) (Darton et al., 2017). Other studies of S. Typhi proteome arrays have shown HlyE as a suitable sero-diagnostic biomarker based on IgG and IgA responses (Liang et al., 2013; Charles et al., 2014; Huw Davies et al., 2016; Darton et al., 2017). OmpA is also seen as a valuable biomarker from proteomic screening (Charles et al., 2014). Salmonella Typhi proteome array screening has 
identified N-acetylmuramoyl-L-alanine amidase (t2002, STY0927) as a new putative biomarkers which is use in the catabolism of peptidoglycans.

During vaccination and cholera infection, antibody in Lymphocyte Supernatant assay (ALS) is used (Chang and Sack 2001), tuberculosis (Raqib et al., 2003) and influenza (Halliley et al., 2010). This has been used to detect S. Typhi antibodies in infected cohorts (Sheikh et al., 2009). Antibody in Lymphocyte Supernatant assay is applied to translate new sero-diagnostic markers through immune-profiling to detect immune-dominant antigens (Charles et al., 2014; Darton et al., 2017). Putative protein targets that should be considered for future diagnostic development in RDTs are IgA, S. Typhi LPS and IgG for better diagnostic results in resource-limited settings (Darton et al., 2017).

\subsection{Metabolomics}

Metabolomics is a new technique of scientific research, which was developed to identify and measure minute quantities of small chemicals in complex biological material using cutting-edge mass spectrometry (Zurfluh et al., 2018). Progress has been made to validate the diagnosis of enteric fever by using diagnostic metabolites in plasma from patients (Nasstrom et al., 2014). This technique is useful to several infectious diseases, detecting signatures of urinary tract infections, inflammatory disease and viral infections (Capati et al., 2017; French et al., 2018; Shrinet et al 2016). Furthermore, it is could predict disease outcomes, progression, and even onset, as was recorded in tuberculosis (Weiner et al., 2018). This technique was used to produce metabolites signatures on plasma samples by 2-dimensional gas chromatography with time of-flight mass spectrometry from 50 typhoid fever patients ( 25 with S. Typhi and 25 with S. Paratyphi A) against 25 febrile controls (Nasstrom et al., 2014). It has been identified and validated that significant and reproducible metabolomics signatures could separate typhoid and other febrile illness with asymptomatic controls in a Nepali patient cohort (Nasstrom et al., 2014; Nasstrom et al., 2017) 
This diagnosis compares the metabolites profiles of healthy and infected persons with typhoid and paratyphoid. Threshold is determined to single out those with acute typhoid fever (McKinnon and Abdool 2014)

\subsection{Transcriptomics}

Transcriptomics require the measurement of gene expression in a given cellular compartment at a specific time. The transcript mRNA is measured and quantity by calculating the amount of mRNA transcribed from genomic DNA using microarrays and RNAseq high-throughput molecular technology. Profiles can be produced from a small quantity of biological sample, such as whole blood (Nakaya et al., 2016). Therefore, transcriptomic has been used to generate detailed insights into the human transcriptional response to several diseases (Berry et al., 2010; Mejias et al., 2013; Subramaniam et al., 2015; Hoang et al., 2010; Barton et al., 2017; Blohmke et al., 2016) and other alternative immune perturbations (Vahey et al., 2010; Nakaya et al., 2011; Blohmke et al., 2017; Li et al., 2017). The human challenge model has been the source of various gene expression datasets, which were generated in a highly controlled setting, allowing the interrogation of the human transcriptional responses to S. Typhi and S. Paratyphi A (Barton et al., 2017; Blohmke et al., 2016; Blohmke et al., 2019). This techniques use the response of the host as a possible biomarkers that are specific to identify typhoid fever patients. It confirms that gene expression profiles are specific enough to possibly differentiate diseases with similar clinical presentation (Gliddon et al., 2018). This is a powerful tool to detect new diagnostic biomarkers for diseases and could represent the future of molecular diagnostics for typhoid fever.

\subsection{Genomics}

This technique has allowed for $S$. Typhi genome sequencing and assisted in the recognition of specific gene targets. DNA markers that are specific for $S$. Typhi have been identified using the 
genome database and nucleic acid sequence alignment tools (BLASTn). The primer sensitivities and specificities designed for amplifying specific gene sequences were authenticated using $S$. Typhi, non-Typhi Salmonella and non-salmonella clinical isolates (Goay et al., 2016).

\subsection{Other Typhoid Diagnostic Techniques}

Several other techniques aside the new approaches such as molecular detection of bacteria genes using PCR has being the focus of research towards developing an improved typhoid test. PCR technique is a non-culture based techniqus designed to identify the flagellin genes of $S$. Typhi, $S$. Paratyphi A and other specific targets (Zhou et al., 2016; Levy et al., 2008). A PCR-based technique has the capacity to identify bacterial DNA and do not recover living cell. Nevertheless, any pathogen-directed test for S. Typhi/S. Paratyphi A is limited by the low concentration of bacteria in the blood as well the inherent inhibitors in the sample (Nga et al., 2010). Laboratory methods to lyse red blood cells have shown increasing yield (Boyd et al., 2015), and extracting DNA from samples could generate increase yield, thus improving sensitivity and specificity (Zhou and Pollard 2012).

Loop-mediated isothermal amplification (LAMP) is a method for the amplification of nucleic acid at a constant temperature, targeting specific $S$. Typhi gene (Fan et al., 2015; Frickmann et al., 2019).

An attractive approach for typhoid fever diagnostics is the detection of an antibody response signifying recent infection using serum and plasma. The most promising targets identified through serological response are (IgG) and (IgA) to hemolysin E and S. Typhi-specific lipopolysaccharide (LPS) (Davies et al., 2016), IgM and/or IgG to hemolysin E (Liang et al., 2013), and IgA to $S$. Typhi-specific LPS (Darton et al., 2017).

Widal test (WT) measures agglutinating antibodies against lipopolysaccharide (LPS) (O) and flagellar (H) antigens of $S$. Typhi in the sera of typhoid fever patient (WHO 2019). This technique 
is unreliable with low sensitivity and specificity (Maude et al., 2015). Rapid diagnostic tests (RDTs) could detect antigens or antibodies with Typhidot-M ${ }^{\circledR}$ and TUBEX $^{\mathrm{T}}{ }^{\mathrm{M}}$ as the current commercial RDTs for typhoid fever (Thriemer et al., 2013; Baker et al., 2010). Salmonella Typhi antibodies specific to LPS antigens are detected by Enterocheck WB techniques in a lateral flow format similar to ICT. Negative result is indicative of the absence of pink to pink-purple coloured band in the test area (Mogasale et al., 2016; Darton et al., 2017). Blood culture technique is considered the reference standard for enteric fever diagnosis (Paolucci et al., 2010; Martiny et al., 2013). The sensitivity of culture specimens differs considerably depending on the type and volume of fluid analysed, prior antimicrobial use, age of the infected person and period of ailment. Bone marrow culture is obtained through aspirate of the iliac crest or sternum with a sensitivity of approximately 90\% when the culture is over 4 days (Crump et al., 2015; Gilman et al., 1975; Darton et al., 2017).

\section{RESEARCH METHODOLOGY}

\subsection{Research design}

The analysis of the research design was a quantitative method with a survey approach which involves five respective steps: identification of studies; selection of articles; quality assessment of studies; extraction of data; and data analysis.

\subsection{Search strategy for identification of relevant articles}

A search strategy was designed to identify all articles in English that assessed enteric fever diagnostic protocols among humans. Published peer-reviewed articles of diagnostic protocol for enteric fever were identified from Google scholar, PubMed, and MEDLINE databases. The search words were enteric fever, novel typhoid diagnostic, cultural diagnostic test, diagnostic protocol of typhoid, rapid diagnostic test and widal test for trials in progress. 


\subsection{Search outcome}

In all, three hundred and ninety two (392) articles were identified and screened (Figure 1). 355 articles were excluded after reviewing the articles based on the following: duplicates 94, misleading titles and abstract 102, articles without Widal and rapid diagnostic test 91, articles that do not meet quality criteria 68 .

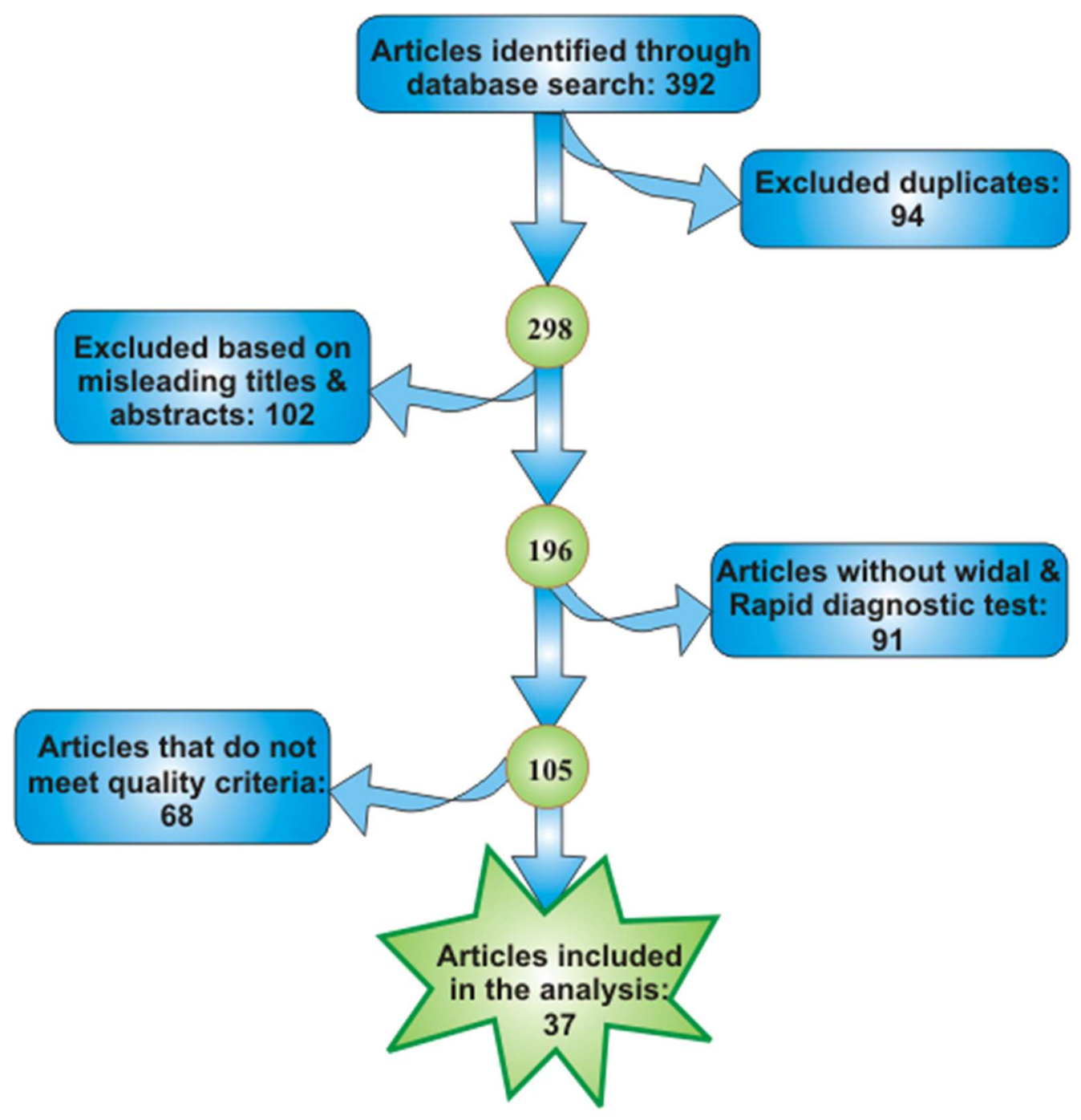

Figure 1: Flowchart of published peer-reviewed journals detected through databases and included in the analysis. 


\subsection{Inclusion and exclusion criteria}

Studies in English language were included without restrictions on country, age, demographics, or time. Cross-sectional studies, paired comparative study, prospective cohort studies, and retrospective studies were included. Studies that do not meet quality criteria were excluded.

\subsection{Ethics statement}

All studies included were those approved by an institutional ethics review committee in addition obtained informed consent from all their participants. Ethics approval was not requisite for the present study as it is based on secondary data generated from the primary source.

\subsection{Statistical analysis}

The data obtained from the literature were entered into Microsoft Excel and Statistical Package for the Social Science (SPSS), version 25.0 for windows (SPSS Inc., Chicago, Illinois, USA) and were used for descriptive analysis of the data. The results are presented as percentages. Independent sample $t$-test was used to explore differences in the mean percentage sensitivity of diagnostic tests. The level of statistical significance was set at $P<0.05$.

\section{RESULTS}

\section{Results of electronic search}

The results of the synthesis from the studies collected by the literature review are presented in the Table 1. Of the 392 searched articles, 37(9.4\%) articles met the inclusion criteria with 11,525 participants (Table 1). Exactly 27 studies use widal test, 5 use TUBEX, 15 use Typhidot (Typhidot, Typhidot-M, and TyphiRapid-Tr02), 1 use Diazo test, 2 use Enterocheck WB ${ }^{\circledR}, 2$ use Multiplex PCR, 1 use ONSITE Typhoid Combo, 1 Multi-test dipstick, and 2 Panbio ELISA. Studies that used the gold standard for comparison were 31. All of the diagnostic tests were developed to 
identify $S$. Typhi infection and Paratyphi. $34.4 \%$ of the studies in this review used prospective study design. 
1 Table 1: Diversity of Typhoid fever diagnostic protocols and accuracy values

\begin{tabular}{|c|c|c|c|c|c|c|c|c|c|c|}
\hline $\begin{array}{l}\text { Diagnostic } \\
\text { tests }\end{array}$ & Study design & $\begin{array}{l}\text { Sample } \\
\text { size } \\
(11,525)\end{array}$ & $\begin{array}{l}\text { Gold } \\
\text { Standard }\end{array}$ & Country & $\begin{array}{l}\text { Prev } \\
(\%)\end{array}$ & $\begin{array}{l}\text { Sen } \\
(\%)\end{array}$ & $\begin{array}{l}\text { Spec } \\
(\%)\end{array}$ & $\begin{array}{l}\text { PPV } \\
(\%)\end{array}$ & $\begin{array}{l}\text { NPV } \\
(\%)\end{array}$ & Citations \\
\hline Widal & $\begin{array}{l}\text { Cross- } \\
\text { sectional }\end{array}$ & 372 & $\begin{array}{l}\text { Stool } \\
\text { culture }\end{array}$ & Ethiopia & 56.2 & 80 & 44.5 & 3.8 & 98.8 & $\begin{array}{l}\text { Deksisa \& Gebremedhin } \\
2019\end{array}$ \\
\hline Widal & $\begin{array}{l}\text { Cross- } \\
\text { sectional }\end{array}$ & 95 & $\begin{array}{l}\text { Stool } \\
\text { culture }\end{array}$ & Ethiopia & 68.4 & 84.2 & 35.5 & 24.6 & 90 & Ameya et al., 2017 \\
\hline Widal & $\begin{array}{l}\text { Randomized } \\
\text { design }\end{array}$ & 125 & $\begin{array}{l}\text { Stool } \\
\text { Culture }\end{array}$ & Nigeria & 17.6 & 78.3 & 93.6 & 68.2 & 98.1 & Minjibir et al 2020 \\
\hline Widal & $\begin{array}{l}\text { Cross } \\
\text { sectional }\end{array}$ & 158 & $\begin{array}{l}\text { Stool } \\
\text { Culture }\end{array}$ & Tanzania & 81 & 81.5 & 18.3 & 10.1 & 89.7 & Mawazo et al 2019 \\
\hline Widal & $\begin{array}{l}\text { Prospective } \\
\text { study }\end{array}$ & 810 & $\begin{array}{l}\text { Blood and } \\
\text { stool } \\
\text { culture }\end{array}$ & Nigeria & NR & 49.1 & 90.7 & 46.2 & 91.6 & Ohanu et al. 2019 \\
\hline
\end{tabular}




\begin{tabular}{|c|c|c|c|c|c|c|c|c|c|c|}
\hline Widal & $\begin{array}{l}\text { Cross- } \\
\text { sectional }\end{array}$ & 91 & $\begin{array}{l}\text { Stool } \\
\text { culture }\end{array}$ & Nigeria & 62.5 & 71.4 & 66.7 & 83.3 & 50 & Ramyi et al., 2013 \\
\hline Widal & NR & 71 & PCR & India & NR & 50 & 50 & 92.8 & 39.5 & Ambati et al., 2007 \\
\hline Widal & $\begin{array}{l}\text { Comparative } \\
\text { study }\end{array}$ & 112 & $\begin{array}{l}\text { Stool } \\
\text { culture }\end{array}$ & Cameroon & 57.1 & 40.9 & 32.4 & 6.44 & 28.1 & Wam et al., 2019 \\
\hline Widal & $\begin{array}{l}\text { Cross- } \\
\text { sectional }\end{array}$ & 158 & $\begin{array}{l}\text { Stool and } \\
\text { blood } \\
\text { culture }\end{array}$ & NR & 81 & 81.5 & 18.3 & 10.1 & 89.7 & Mawazo et al., 2019 \\
\hline Widal & $\begin{array}{l}\text { Retrospective } \\
\text { study }\end{array}$ & 100 & $\begin{array}{l}\text { Blood } \\
\text { Culture }\end{array}$ & India & NR & 71.4 & 47.3 & 9.25 & 95.7 & Lalremruata et al., 2014 \\
\hline Widal & $\begin{array}{l}\text { Prospective } \\
\text { study }\end{array}$ & 270 & $\begin{array}{l}\text { Blood } \\
\text { culture }\end{array}$ & Ethiopia & 32.6 & 71.4 & 68.4 & 5.7 & 98.9 & Andualem et al., 2014 \\
\hline Widal & $\begin{array}{l}\text { Prospective } \\
\text { study }\end{array}$ & 163 & $\begin{array}{l}\text { Blood } \\
\text { culture }\end{array}$ & India & 54 & 65.4 & 89.8 & NR & NR & Maheshwari et al., 2016 \\
\hline Widal & $\begin{array}{l}\text { Cross- } \\
\text { sectional }\end{array}$ & 271 & $\begin{array}{l}\text { Blood } \\
\text { culture }\end{array}$ & Nigeria & 45.76 & 35 & 51 & 17 & 73 & Enabulele \&Awunor 2016 \\
\hline
\end{tabular}




\begin{tabular}{|c|c|c|c|c|c|c|c|c|c|c|}
\hline TUBEX & $\begin{array}{l}\text { Comparative } \\
\text { study }\end{array}$ & 139 & $\begin{array}{l}\text { Blood } \\
\text { culture }\end{array}$ & Tanzanian & NR & 79 & 89 & NR & NR & Ley et al., 2011 \\
\hline TUBEX & $\begin{array}{l}\text { Retrospective } \\
\text { study }\end{array}$ & 970 & $\begin{array}{l}\text { Blood } \\
\text { culture }\end{array}$ & Pakistan & 1.86 & 41.9 & 96 & 31.6 & 97.3 & Khan et al., 2017 \\
\hline Typhidot & $\begin{array}{l}\text { Retrospective } \\
\text { study }\end{array}$ & 42 & $\begin{array}{l}\text { Blood } \\
\text { culture }\end{array}$ & NR & NR & 92.7 & NR & 97.4 & NR & Garg et al., 2018 \\
\hline Typhidot & $\begin{array}{l}\text { Cross- } \\
\text { sectional }\end{array}$ & 211 & $\begin{array}{l}\text { Blood } \\
\text { culture }\end{array}$ & NR & 95.9 & 95.9 & 26.5 & 30.3 & 96 & Hussain et al., 2018 \\
\hline Typhidot & $\begin{array}{l}\text { Prospective } \\
\text { study }\end{array}$ & 500 & NR & Cambodia & 63.6 & 63.6 & 82.9 & 26.4 & 95.9 & Ameya et al., 2017 \\
\hline Typhidot & $\begin{array}{l}\text { Retrospective } \\
\text { study }\end{array}$ & 145 & $\begin{array}{l}\text { Blood } \\
\text { Culture }\end{array}$ & NR & 32.4 & 26.7 & 61.5 & 7.4 & 87.9 & Mehmood et al., 2015 \\
\hline $\begin{array}{l}\text { Multiplex } \\
\text { PCR }\end{array}$ & $\begin{array}{l}\text { Prospective } \\
\text { study }\end{array}$ & 680 & $\begin{array}{l}\text { Blood } \\
\text { culture }\end{array}$ & Bangladesh & 20 & 95 & 92.9 & NR & NR & Ambati et al., 2007 \\
\hline Enterocheck & $\begin{array}{l}\text { Prospective } \\
\text { study }\end{array}$ & 145 & $\begin{array}{l}\text { Blood } \\
\text { Culture }\end{array}$ & NR & NR & 85.5 & 88.6 & 51.1 & 97.7 & Baker et al., 2010 \\
\hline
\end{tabular}




\begin{tabular}{|c|c|c|c|c|c|c|c|c|c|c|}
\hline Widal & Prospective & & Blood & & 62.5 & 71 & 62 & 91 & 31 & \\
\hline Widal & study & & culture & India & NR & 71 & 62 & 91 & 31 & Aziz \& Haque 2012 \\
\hline PCR & Comparative & & Blood & & & 100 & 86.5 & & & \\
\hline Widal & study & 76 & culture & NR & NR & 88.6 & 62.5 & NR & NR & El-Sayed et al., 2015 \\
\hline Widal & Comparative & & Blood & & 45.7 & 34.1 & 42.8 & & & \\
\hline Typhidot & study & 105 & culture & India & 74.3 & 92.6 & 37.5 & NR & NR & Narayanappa et al., 2010 \\
\hline Typhidot & & & Blood & & 97.36 & 96 & 89.5 & 95 & & \\
\hline Widal & NR & 124 & culture & NR & 73.68 & 72 & 87 & 87 & NR & Khoharo 2011 \\
\hline Widal & Comparative & & Blood & & 35 & 86.7 & 89.5 & 79.5 & 93.4 & \\
\hline Typhidot & study & 140 & culture & Egypt & 36.5 & 93.3 & 90.6 & 82.3 & 96.6 & Salama \& Said 2019 \\
\hline Widal & Comparative & & & & 48.1 & & & 94 & & \\
\hline Widal & study & 100 & NR & India & 26 & NR & NR & 52 & NR & Patel \& Trivedi 2017 \\
\hline Widal & Comparative & & Blood & & 57 & 57 & 83 & & & \\
\hline Typhidot & study & - & culture & New Delhi & 79 & 79 & 87.5 & NR & NR & Sherwal et al., 2004 \\
\hline
\end{tabular}




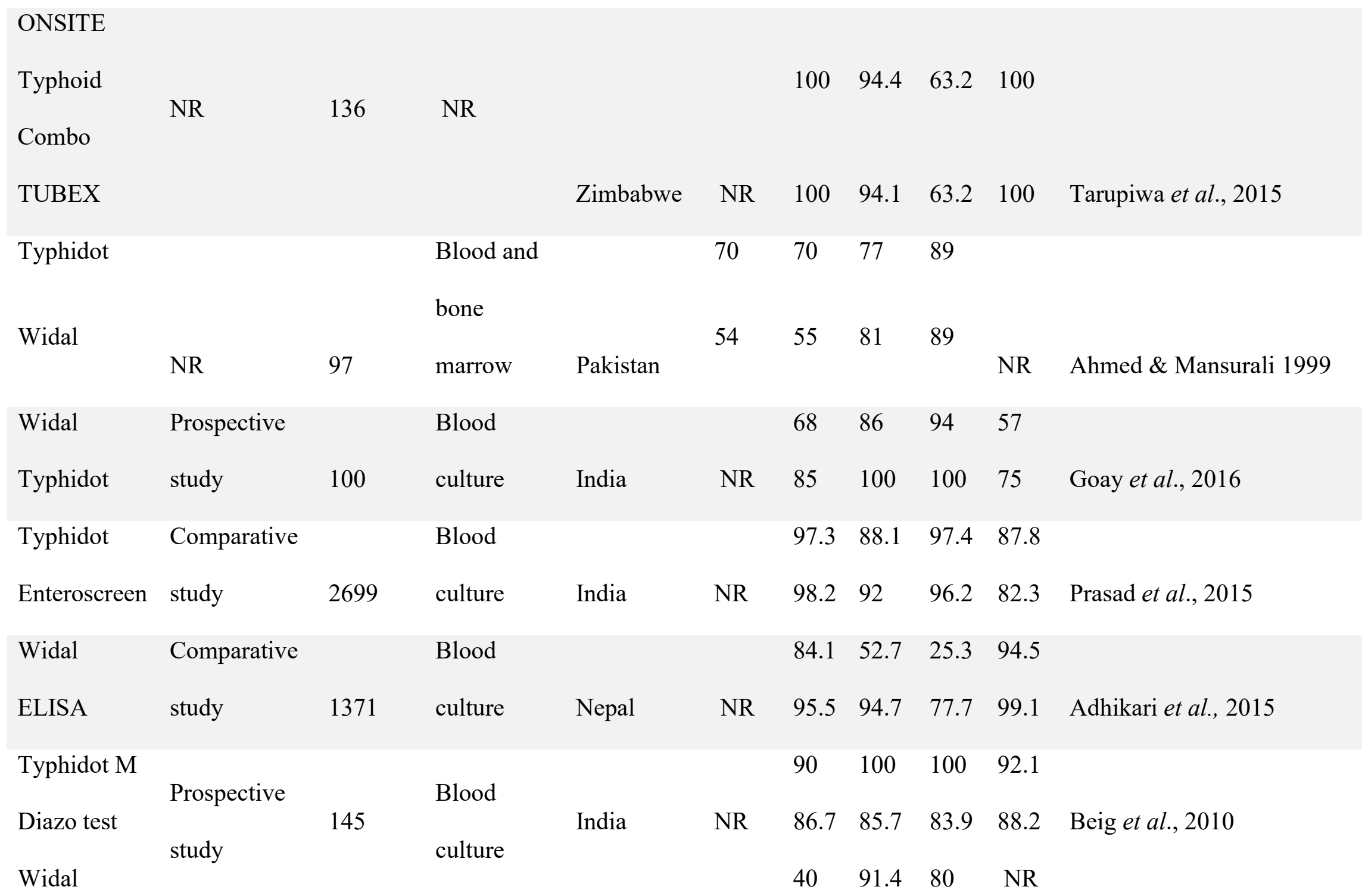




\begin{tabular}{|c|c|c|c|c|c|c|c|c|c|c|}
\hline \multicolumn{11}{|l|}{ Panbio } \\
\hline & \multirow{4}{*}{$\begin{array}{l}\text { Prospective } \\
\text { study }\end{array}$} & \multirow{4}{*}{144} & \multirow{4}{*}{ NR } & \multirow{4}{*}{ NR } & 84 & 78 & 80 & 68.4 & \multirow{2}{*}{\multicolumn{2}{|c|}{87.4}} \\
\hline LLISA & & & & & & & & & & \\
\hline Widal & & & & & & 98 & 76.6 & 69 & 98.6 & \\
\hline Typhidot & & & & & & 98 & 76.6 & 98.6 & 69 & Anagha et al., 2012 \\
\hline TUBEX & \multirow{5}{*}{ NR } & \multirow{5}{*}{500} & \multirow{5}{*}{$\begin{array}{l}\text { Blood } \\
\text { culture }\end{array}$} & \multirow{5}{*}{ Guinea } & 15 & 51.1 & 88.3 & 0.31 & 0.95 & \multirow{5}{*}{ Siba et al., 2012} \\
\hline Typhidot & & & & & 23 & 70 & 80.1 & 0.26 & 0.96 & \\
\hline $\begin{array}{l}\text { TyphiDot } \\
\text { Rapid (TR- }\end{array}$ & & & & & 22 & 89.4 & 85 & 0.38 & 0.99 & \\
\hline 02) & & & & & & & & & & \\
\hline Widal & & & & & 8 & 51.1 & 95.8 & 0.56 & 0.95 & \\
\hline Multi-test & \multirow{5}{*}{$\begin{array}{l}\text { Prospective } \\
\text { study }\end{array}$} & \multirow{5}{*}{80} & \multirow{5}{*}{ NR } & \multirow{5}{*}{ Vietnam } & \multirow{5}{*}{ NR } & 89 & 50 & 85 & 60 & \\
\hline Dipstick & & & & & & & & & & \\
\hline Typhidot & & & & & & 79 & 89 & 96 & 59 & \\
\hline TUBEX & & & & & & 78 & 94 & 98 & 59 & \\
\hline Widal & & & & & & 64 & 76 & 88 & 48 & Olsen et al., 2004 \\
\hline
\end{tabular}




\section{Sensitivity, Specificity, Positive Predictive Value (PPV), Negative Predictive Value (NPV)}

The percentage sensitivity, specificity, PPV, and NPV of the data obtained are presented in Table 1. The average sensitivity of $52.9 \%$ (figure 2), average specificity of 54\% (figure 3), average PPV of $56.8 \%$ (figure 4), and average NPV of 55.6\% (figure 5) was determine in Widal test while $29.4 \%, 28 \%, 29.5 \%$, and $27.8 \%$ was determine in Typhidot respectively. There was a statistical evidence to demonstrate that there was a significant different between Widal test and Typhidot. The diagnostic accuracy of Widal was moderate compared to others.

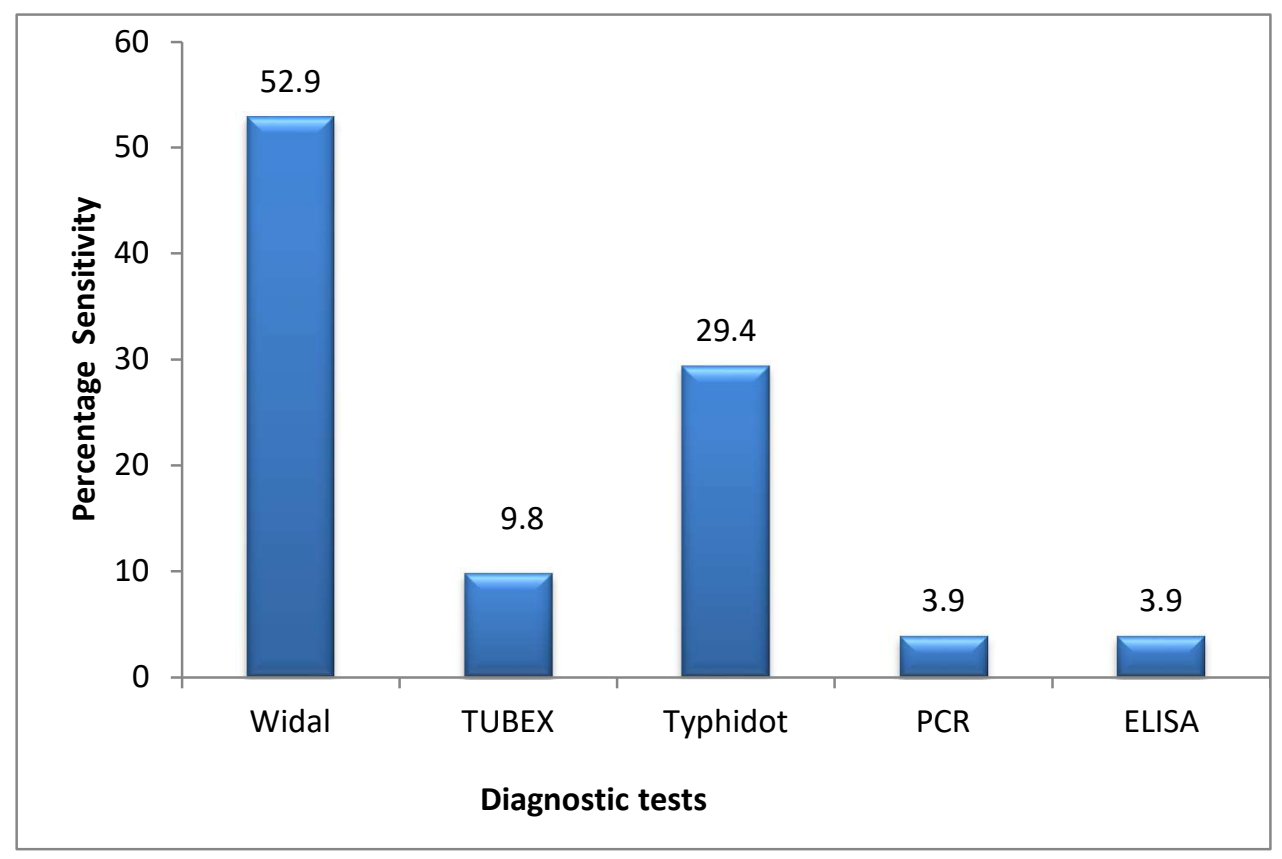

Figure 2: The mean percentage sensitivity of typhoid fever diagnostic techniques 


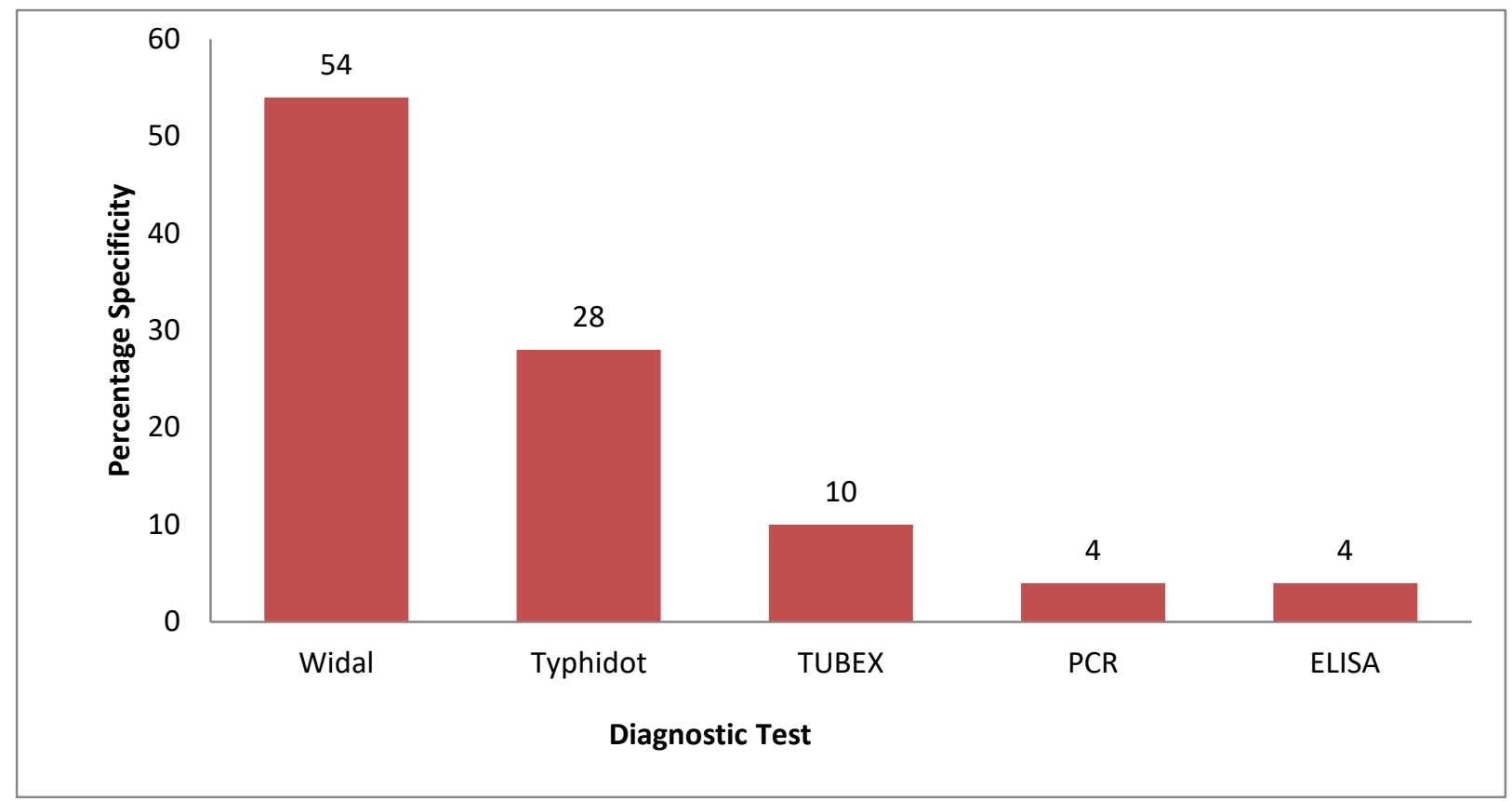

Figure 3: Mean percentage specificity of typhoid fever diagnostic techniques

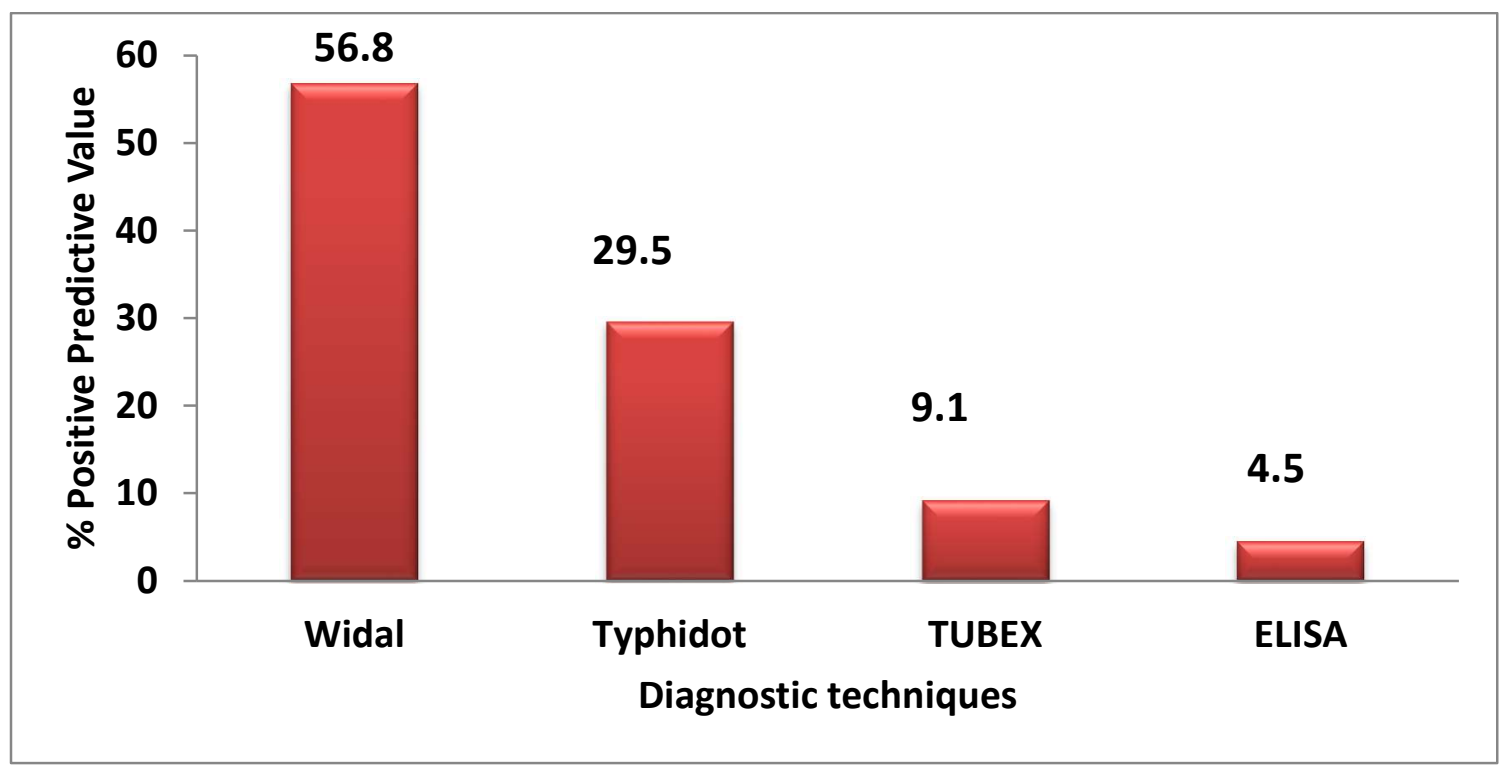

Figure 4: Mean percentage positive predictive value of typhoid fever diagnostic technique 


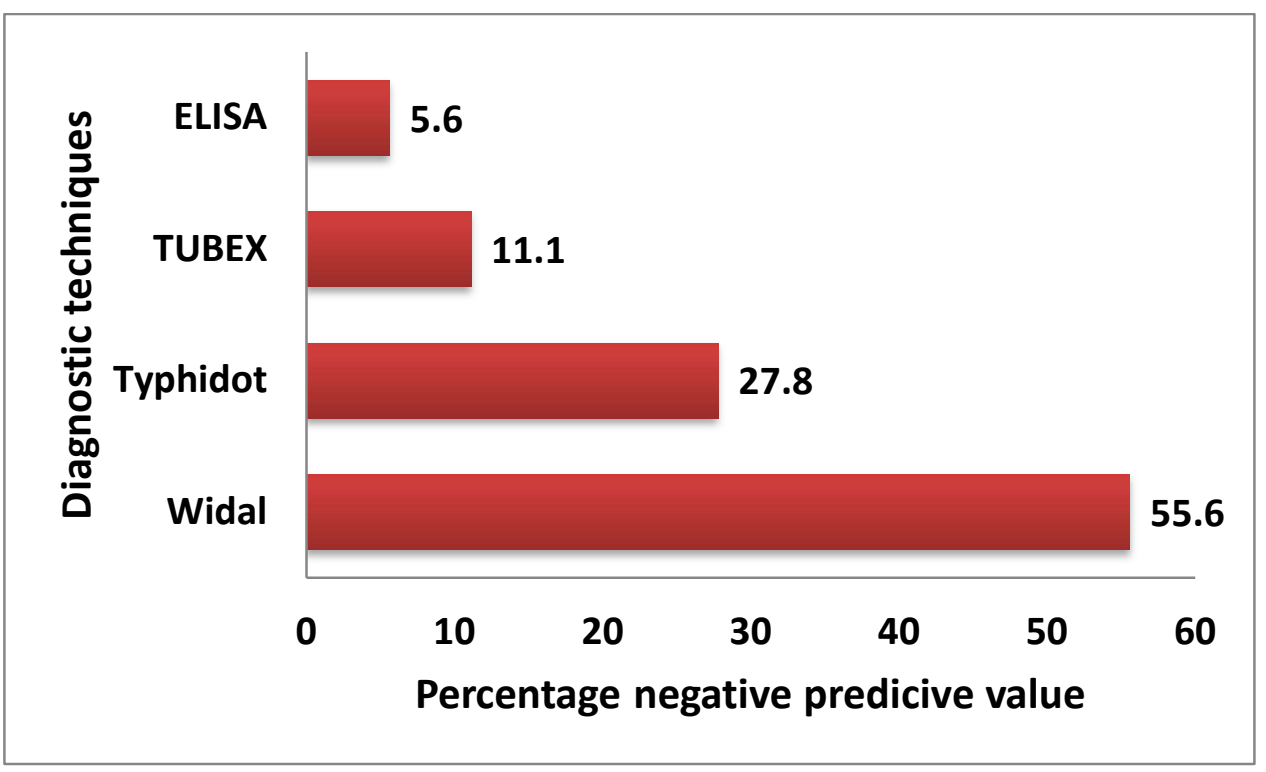

Figure 5: Mean percentage negative predictive value of typhoid fever diagnostic techniques

\section{Discussion}

This study reveals a moderate average diagnostic accuracy of Widal test in the diagnosis of TF. A clinically diagnosis requires high values for both sensitivity and specificity. TF diagnosis actually begins with the evaluation of clinical signs and symptoms. Different diagnostic tools are used for enteric fever diagnosis and include cultures from blood, bone marrow, urine and stool. Recently, diagnostic tools such as proteomics, transcriptomics, metabolomics and genomics have been exploited to detect biomarkers unique to $S$. Typhi (Sharma et al., 2018). The sensitivity of any diagnostic test is the percentage of patients that are positive and are appropriately identified with the ailment. However, specificity is the percentage of patients that are properly diagnosed as negative. The probability that those confirmed positive by the techniques are actually having the disease is positive predictive value (PPV) while the probability that those confirm negative by the techniques are actually not infected is negative predictive value (NPV). 
Several gold standard techniques have been used to assess typhoid diagnostics, with blood culture being the most used techniques. The lack of perfect gold standards is a major challenge with assessing the accuracy of typhoid diagnostics. Blood cultures, which has a near perfect specificity, is only $50-65 \%$ sensitive. Storey et al. (2015) reveal that no single test has adequately good performance but recommended that some existing techniques could be useful as composite reference standard.

The study reveals that the combinations of existing sensitive and specific techniques could surmount the limitations of accuracy that is intrinsic in single test. The application of composite reference standard could enhance better estimates for test performance based on combinations of tests. The purpose of this study is to evaluate typhoid diagnostic accuracy and the urgent need for the best components of a typhoid CRS in other to establish a standardized composite reference as novel typhoid protocol. This will enable careful comparison of diagnostic accuracy data across studies, which is often difficult because of varying study designs and reference standards. To authenticate the diagnostic accuracy of a new test, results from several studies is required. Furthermore, the use of CRS will enhance confidence in prevalence estimates, which could help guide typhoid vaccination efforts. A new CRS for typhoid may still be imperfect compared to diagnostic truth, but there is much to gain from the approval of a standardized composite reference. There is an urgent need for better diagnostic tests to detect enteric fever in order to improve disease burden estimates and potentially accelerate the adoption of new typhoid vaccines (Crump and Mintz 2010; DeRoeck et al., 2005). In order to achieve this, standardization, and broad approval of a single reference standard based on a composite reference are required. 


\section{Challenges and future outlook}

Identifying real typhoid patients with negative blood culture is a significant constrain in enteric fever diagnosis (Moore et al., 2014). Indistinguishable clinical symptoms and the absence of a reliable gold standard test complicate typhoid diagnosis. About $20 \mathrm{~mL}$ to $30 \mathrm{~mL}$ of blood is needed for the detection of blood related infections and this poses a challenge for elderly and neonatal patients (Mancini et al., 2010). Additionally, lack of funding support, research capacity, and lack of institutional infrastructure are challenges facing TF diagnosis and other infectious diseases, especially in Nigeria. Absence of perfect test leads to unwise antibiotic use, resulting to complications, morbidity as well as drug resistance.

A diagnostic technique requiring small blood volumes with quick and correct detection is thus required. Furthermore, the quality of a reliable future evaluation of enteric fever diagnosis can be improved by the use of composite reference standard CRS, which will enhance assurance in prevalence estimates and avoid inappropriate intake of antibiotics by patients that do not need it. Future research should employ a prospective cohort design with CRS as a diagnostic tool. From our outlook, metabolite profiles are possible future solution for diagnosing typhoid fever, but there are many challenges in making these indicative chemical signatures routinely accessible. The use of CRS as upgraded reference standard for typhoid fever diagnosis will improve the actual worldwide burden of typhoid widespread.

\section{Limitations and strengths}

Limitations in this study arise from the variety of diagnostic technique used by several investigators, as well as the way those tests were conducted. As a result, many articles could not be included in the analysis. Also, this analysis was based on published literature only. Regardless of these limitations, the strength of this study is the thorough review of published peer review 
articles assessing the current trend and performance of various diagnostic protocols for the detection of enteric fever.

\section{Conclusions and recommendations}

In conclusion, it is a real possibility to eliminate typhoid fever, but novel diagnostics is necessary and should be factored into future trajectory for the disease control. This study found a diverse evidence of typhoid diagnostics with a substantial degree of variation in typhoid fever testing. The principle finding of this study reveals that the diagnostic performance of Widal test was moderate at a sensitivity of $52.9 \%$. The combination of imperfect tests to determine typhoid fever disease status is a transparent technique to deal with the challenge of imperfect reference standard However, the study proposes the combinations of peripheral blood culture and Widal test as a composite reference standard which will possibly improve confidence in prevalence estimate.

Conflict of interest: The authors declare that there are no conflicts of interest.

Authors' contributions: Author BEI got the concept. The study design and data analysis was performed by S.I.R.O. and B.E.I. Author B.E.I, I.B.O and S.A.M participated in the drafting of the manuscript, which was critically reviewed for important intellectual content by S.I.R.O, A.B, and O.M.O. Interpretation of data obtained was done by S.A.M, S.I.R.O, I.B.O and A.B. The statistical analysis was performed by B.E.I and O.M.O. All authors read and approved the final version of the revised manuscript for publication. 


\section{References}

Storey H. L, Huang Y, Crudder C, Golden A, de los Santos T, Hawkins K (2015). A MetaAnalysis of Typhoid Diagnostic Accuracy Studies: A Recommendation to Adopt a Standardized Composite Reference. PLoS ONE. 10(11):e0142364-2.

Adhikari A, Rauniyar R, Raut PP, Manandhar KD, Guta BP. Evaluation of Sensitivity and Specificity of ELISA against Widal test for Typhoid Diagnosis in Endemic Population of Kathmandu. BMC Infect Dis 2015; 15:523

Ahmed Z, Mansurali N. Rapid Serologic Diagnosis of Pediatric Typhoid Fever in an Endemic Area: A Prospective Comparative Evaluation of two dot-enzyme Immunoassays and the Widal Test. Amer J Trop Med Hyg 1999;61(4):654-7.

Alba S, Bakker MI, Hatta M, Scheelbeek PFD, Dwiyanti R, Usman R, Tandiriang N, Anur M, Sultan AR, Sabir M, Yasir Y. Risk Factors of Typhoid Infection in the Indonesian Archipelago. PLoS One 2016;11

Alonzo T A, Pepe M S. Using a combination of reference tests to assess the accuracy of a new diagnostic test. Stat Med 1999; 18, 2987-3003

Ambati SR, Nath G, Das BK. Diagnosis of Typhoid Fever by Polymerase Chain Reaction,

Ameya G, Atalel E, Kebede B, Yohannes B. Comparative Study of Widal test against Stool [ Culture for Typhoid Fever Suspected Cases in Southern Ethiopia. Path Lab Med Int 2017;9:1.

Anagha K, Deepika B, Shahriar R, Sanjeev K. The Easy and Early Diagnosis of Typhoid Fever. J Clin Diagnost Research, 2012; 6(2):198-9..

Andrews JR, and Ryan ET. Diagnostics for Invasive Salmonella Infections; Current Challenges and Future Directions. Vacine 2015;33(3):C8-15

Andualem G, Tamrat A, Nigatu K, Gebre-Selassie S, Mihret A, Alemayehu H. A Comparative

Study of Widal test with Blood Culture in the Diagnosis of Typhoid Fever in Febrile Patients. BMC Research Notes 2014;7:653

Antillón M, Warren J L, Crawford F W, et al. The burden of typhoid fever in low- and middle-income countries: a meta-regression approach. PLoS Negl Trop Dis 2017; 11

Archibald LK, Reller LB. Clinical Microbiology in Developing Countries. Emerging Infect Dis 2001;7:302-305

Aziz T, Haque SS. Role of Widal test in the Diagnosis of Typhoid Fever in Context to other

Baker S, Favorov M, Dougan G. Searching for the elusive typhoid diagnostic. BMC Infect Dis 2010; 10: 45.

Barton A.J, Hill J, Pollard A.J, Blohmke C.J. Transcriptomics in human challenge models. Front Immunol 2017; 8:1839.

Beig FK, Ahmad F, Ekram M, Shukla I. Typhidot M and Diazo test vis-à-vis Blood Culture and Widal test in the early Diagnosis of Typhoid Fever in Children in a Resource Poor Setting, Brazilian J Infect Dis 2010;14(6).

Berry MP, Graham CM, McNab FW, et al. An interferon-inducible neutrophildriven blood transcriptional signature in human tuberculosis. Nature 2010; 466:973-7.

Blohmke CJ, Darton TC, Jones C, Suarez NM, Waddington CS, Angus B, Zhou L, Hill J, Clare S, Kane L, Mukhopadhyay S. Interferon-driven alterations of the Host's amino acid Metabolism in the Pathogenesis of Typhoid Fever. J Exper Med 2016;213: 106177. 
Blohmke C. J, Muller J, Gibani M. M, et al. Diagnostic host gene signature for distinguishing enteric fever from other febrile diseases. EMBO Mol Med 2019; 11: e10431.

Blohmke C.J, Darton T.C, Jones C, et al. Interferon-driven alterations of the host's amino acid metabolism in the pathogenesis of typhoid fever. $J$ Exp Med 2016; 213:1061-77.

Blohmke C.J, Hill J, Darton T.C, et al. Induction of cell cycle and NK cell responses by liveattenuated oral vaccines against typhoid fever. Front Immunol 2017; 8:1276.

Boyd M. A, Tennant S. M, Melendez J. H, et al. Adaptation of red blood cell lysis represents a fundamental breakthrough that improves the sensitivity of Salmonella detection in blood.

J Appl Microbiol 2015; 118:1199-209.

Britto C, Pollard AJ, Voysey M, Blohmke CJ. An appraisal of the clinical features of pediatric enteric fever: systematic review and meta-analysis of the age-stratified disease occurrence. Clin Infect Dis 2017; 64:1604-11.

Buckle GC, Walker CLF, Black RE. Typhoid Fever and Paratyphoid Fever: Systematic Review to Estimate Global Morbidity and Mortality for 2010. J Glob Health 2012;2(1).

Capati A, Ijare OB, Bezabeh T. Diagnostic applications of nuclear magnetic resonance- based urinary metabolomics. Magn Reson Insights 2017; 10:1178623X17694346.

Chang H. S, Sack D.A. Development of a novel in vitro assay (ALS assay) for evaluation of vaccine-induced antibody secretion from circulating mucosal lymphocytes. Clin. Diagn. Lab. Immunol, 2001; 8, 482-488.

Charles R.C, Liang L, Khanam F, Sayeed M. A, Hung C, Leung D.T, Baker S, Ludwig A, Harris J.B, LaRocque R.C, et al. Immunoproteomic analysis of antibody in lymphocyte supernatant in patients with typhoid fever in Bangladesh. Clin. Vaccine Immunol. CVI 2014;21, 280-285.

Charles RC, Liang L, Khanam F, Sayeed MA, Hung C, Leung DT, Baker S, Ludwig A, Harris JB, Larocque RC, Calderwood SB. Immunoproteomic Analysis of Antibody-in - Lymphocyte Supernatant (ALS) in Patients with Typhoid Fever in Bangladesh. Clin Vaccine Immunol 2014;21(3): 280-5.

Crump JA, Mintz E D. Global Trends in Typhoid and Paratyphoid Fever. Clin Infect Dis 2010; 50: 241-246

Crump JA, Sjolund-Karlsson M, Gordon MA, Parry CM. Epidemiology, Clinical Presentation, Laboratory Diagnosis, Antimicrobial Resistance, and Antimicrobial Management of Invasive Salmonella Infections. Clin Microbiol Rev 2015; 28:901-37.

Crump JA, Luby SP, Mintz ED. The global burden of typhoid fever. Bull World Health Organ 2004; 82:346-53.

Crump JA, Ram PK, Gupta SK, Miller MA, Mintz ED. Part I. Analysis of data gaps pertaining to Salmonella enterica serotype Typhi infections in low and medium human S development index countries, 1984-2005. Epidemiol Infect 2008; 136:436-48.

Darton T. C, Blohmke C. J, Pollard A. J. Typhoid epidemiology, diagnostics and the human challenge model.Curr Opin Gastroenterol 2014; 7-17

Darton T. C, Jones C, Dongol S, Voysey M, Blohmke C. J, Shrestha R, Karkey A, Shakya M, Arjyal A, Waddington C. S, et al. Assessment and Translation of the Antibody-inLymphocyte Supernatant (ALS) Assay to Improve the Diagnosis of Enteric Fever in Two Controlled Human Infection Models and an Endemic Area of Nepal. Front. Microbiol, 2017; 8

Darton TC, Blohmke CJ, Giannoulatou E, Waddington CS, Jones C, Sturges P, Webster C, Drakesmith H, Pollard AJ, Armitage AE. Rapidly Escalating Hepcidin and Associated 
Serum Iron Starvation are features of the Acute Response to Typhoid Infection in Humans. PLoS Negl Trop Diseases, 2015; 9(9):e0004029.

Darton TC, Zhou L, Blohmke CJ, Jones C, Waddington CS, Baker S, Pollard AJ. Blood Culture-PCR to Optimise Typhoid Fever Diagnosis after Controlled Human Infection Identifies Frequent Asymptomatic Cases and Evidence of Primary Bacteraemia. $J$ Infection. 2017;74(4):358-66

Darton TC, Zhou L, Blohmke CJ, Jones C, Waddington CS, Baker S, Pollard AJ. Blood Culture-PCR to Optimise Typhoid Fever Diagnosis after Controlled Human Infection Identifies Frequent Asymptomatic Cases and Evidence of Primary Bacteraemia. $J$ Infection. 2017; 74(4): 358-66.

Darton, T.C, Baker S, Randall, A, Dongol S, Karkey A, Voysey M, Carter M.J, Jones C, Trappl K, Pablo J, et al. Identification of Novel Serodiagnostic Signatures of Typhoid Fever Using a Salmonella Proteome Array. Front. Microbiol. 2017; 8.

Davies DH, Jain A, Nakajima R, et al. Serodiagnosis of acute typhoid fever in Nigerian pediatric cases by detection of serum $\operatorname{IgA}$ and $\operatorname{IgG}$ against hemolysin $\mathrm{E}$ and lipopolysaccharide. Am J Trop Med Hyg 2016; 95:431-9.

Deksisa T, Gebremedhin EZ. A Cross-Sectional Study of Enteric Fever among Febrile Patients at Ambo Hospital. Prevalence, Risk Factors, Comparison of Widal test and Stool Culture and Antimicrobial Susceptibility Pattern of Isolate. BMC Infect Dis 2019;19(1):288.

DeRoeck D, Clemens J D, Nyamete A, Mahoney R T. Policymakers' views regarding the introduction of new-generation vaccines against typhoid fever, shigellosis and cholera in Asia. Vaccine 2005; 2762-2774.

Dutta S, Das S, Mitra U, Jain P, Roy I, Ganguly SS, Ray U, Dutta P, Paul DK. Antimicrobial resistance, virulence profiles and molecular subtypes of Salmonella enterica Serovars Typhi and Paratyphi A Blood isolates from Kolkata, India during 2009-2013. PLoS One 2014;9(8):e101347.

El-Sayed Ahmed KA, El-Shishtawy M, El-Taweel F. Multiplex PCR for Diagnosis of \{ Salmonella Enterica Serovar Typhi. Clin Lab 2015;61(10):1537-43.

Enabulele O, Awunor SN. Typhoid Fever in a Tertiary Hospital in Nigeria; Another look at \{ the Widal Agglutination Test as a Preferred Option for Diagnosis. Nigeria Med $J$ 2016;57(3):145-9.

Fan Fenxia, Pengcheng Du Biao Kan, Meiying Yan. The Development and Evaluation of a LoopMediated Isothermal Amplification Method for the Rapid Detection of Salmonella

enterica serovar Typhi PLOS ONE 2015; DOI:10.1371/journal.pone.0124507

Fan F, Du P, Kan B, Yan M. The development and evaluation of a loop-mediated isothermal amplification method for the rapid detection of Salmonella enteric serovar Typhi. PLoS One 2015; 10:e0124507.

Felgner J, Jain A, Nakajima R, Liang L, Jasinskas A, Gotuzzo E, Vinetz J.M, Miyajima F, Pirmohamed M, Hassan-Hanga F. et al. Development of ELISAs for diagnosis of acute typhoid fever in Nigerian children. PLoS Negl. Trop. Dis 2017; 11, e0005679.

French CD, Willoughby RE, Pan A, et al. NMR metabolomics of cerebrospinal fluid differentiates inflammatory diseases of the central nervous system. PLoS Negl Trop Dis 2018; 12:e007045. 
Frickmann H, Wiemer D.F, Wassill L, et al. Loop-mediated isothermal amplification-based detection of typ hoid fever on an automated Genie II Mk2 system - a case-control-based approach. Acta Trop 2019; 190:293-5.

Garg S, Sankle A, Joshi A, Mehta S. Comparison of Typhidot IgM Test and Blood Culture in Children with Clinically Compatible Enteric Fever. Int $J$ Contemporary Paediat 2018;5(6):2129-32.

Gilman RH, Terminel M, Levine MM, Hernandez-Mendoza P, Hornick RB. Relative Efficacy of Blood, Urine, Rectal Swab, Bone-marrow, and Rose-spot Cultures for Recovery of Salmonella Typhi in Typhoid Fever. Lancet 1975;1(7918):1211-3.

Gliddon H. D, Herberg J. A, Levin M, Kaforou M. Genome-wide host RNA signatures of infectious diseases: discovery and clinical translation. Immunology 2018; 153:171-8.

Goay XY, Chin KL, Tan CLL, Yeoh CY, Ja'afar JN, Zaidah AR, Chinni SV, Phua KK. Identification of Five Novel Salmonella Typhi-specific Genes as Markers for Diagnosis of Typhoid Fever Using Single-gene Target PCR Assays. Biomed Research Int 2016.

Halliley J. L, Kyu S, Kobie J. .J, Walsh E. E, Falsey A. R, Randall T. D, Treanor J, Feng C, Sanz I, Lee F. E. H. Peak frequencies of circulating human influenza-specific antibody secreting cells correlate with serum antibody response after immunization. Vaccine 2010; 28, 3582-3587

Haques A, Ahmed J, Qureshi JA. Early Detection of Typhoid by Polymerase Chain Reaction. Annal Saudi Med 1999;19(4):337-40

Hoang LT, Lynn DJ, Henn M, et al. The early whole-blood transcriptional signature of dengue virus and features associated with progression to dengue shock syndrome in Vietnamese children and young adults. J Virol 2010; 84:12982-94.

Hussain K, Jamal H, Bashur T, Sanaullah IU, Khoso I. Diagnostics Accuracy of Typhidot in Patients of Typhoid Fever. Pat Armed Forces Med J 2018;68(5):1215-8.

Huw D D, Jain A, Nakajima R, Liang L, Jasinskis A, Supnet M, Felgner P.L, Teng A, Pablo J., Molina D.M (2016). Serodiagnosis of Acute Typhoid Fever in Nigerian Pediatric Cases by Detection of Serum IgA and IgG against Hemolysin E and Lipopolysaccharide. Am. J Trop. Med. Hyg. 2016; 95, 431-439.

Igiri BE, Inyang-Etoh PC, Ejezie GC, Jimoh O, Sobo MA, Idoko GO. Diagnostic Investigations \{and Prevalence of Enteric Fever in Ahmadu Bello University Teaching Hospital Shika-Zaria, Kaduna State, Nigeria. Clin Microbiol Infect Dis 2018;3(1):1-5.

Kaforou M, Wright V. J, Levin M. Host RNA signatures for diagnostics: an example from paediatric tuberculosis in Africa. J Infect 2014; 69(Suppl 1):S28-31.

Kantele A, Pakkanen SH, Kattunen R, Kantele JM. Head-to-Head Comparison of Humoral

Immune Response to Vi Capsular Polysaccharide and Salmonella Typhi Ty21a Typhoid Vaccines-a Randomized Trial. PLoS One 2013;8(4):e60583.

Keddy KH, Sooka A, Letsoalo ME, Hoyland G, Chaignat CL, Morrissey AB, Crump JA. Sensitivity and Specificity of Typhoid Fever Rapid Antibody Tests for Laboratory Diagnosis at two sub-Saharan African sites. Bull World Health Organ 2011;89:640-7.

Khan K, Khalid L, Wahid K, Ali I. Performance of TUBEX ${ }^{\circledR}$ TF in the Diagnosis of Enteric Fever in Private Tertiary Care Hospital Peshawar, Pak J Pak Med Asso 2017;67(5): 6614.

Khoharo HK. A Comparative Sudy of the Typhidot (Dot-EIA) and Widal Tests in the Blood Culture Positive Cases of Typhoid Fever. Tropical doctor 2011;41(3):136-8. 
Kumar S, Balakrishna K, Singh GP, Batra HV. Rapid Dtection of Salmonalla Typhi in Foods by Combination of Immunomagnetic Separation and Polymerase Chain Reaction. World J Microbiol Biotechnol 2005;21:625-8.

Lalremruata R, Chadha S, Bhalla P. Retrospective Audit of the Widal test for Diagnosis of Typhoid Fever in Pediatric Patients in an Endemic Region. J Clin Diagnosis Research JCDR 2014; 8(5),DC22.

Lateef A, Olopoenpiaa LA, Kingb AL. Widal Agglutination test- 100 Years Later: Still Plagued by Controversy. Postgrad med J 2000; 6:80-4.

Levy H, Diallo S, Tennant S. M, et al. PCR method to identify Salmonella enteric serovars Typhi, Paratyphi A, and Paratyphi B among Salmonella isolates from the blood of patients with clinical enteric fever. J Clin Microbiol 2008; 46:1861-6.

Ley B, Thriemer K, Ame SM, Mtove GM, Von Seidlein L, Amos B, Ochiai LR. Assessment and Comparative Analysis of a Rapid Diagnostic test (TUBEX ${ }^{\circledR}$ ) for the Diagnosis of Typhoid Fever among Hospitalized Children in Rural Tanzanian, BMC Infect Dis 2011;11(1):147.

Li S, Sullivan N. L, Rouphael N, et al. Metabolic phenotypes of response to vaccination in humans. Cell 2017; 169:862-77.e17.

Liang L, Juarez S, Nga T.V.T, Dunstan S, Nakajima-Sasaki R, Davies, D.H, McSorley S, Baker S, Felgner P.L. Immune profiling with a Salmonella Typhi antigen microarray identifies new diagnostic biomarkers of human typhoid. Sci. Rep.2013; 3, 1043.

Liang L, Juarez S, Nga TVT et al. Immune profiling with a Salmonella Typhi antigen microarray identifies new diagnostic biomarkers of human typhoid. Sci. Rep. 2013; 3:1043

Maheshwari V, Kaore NM, Ramnani VK, Sarda S. A Comparative Evaluation of Different Diagnostic Modalities in the Diagnosis of Typhoid Fever using a Composite Reference Standard; a Tertiary Hospital based Study in Central India. J Clin Diagn Res 2016;10(10):DC01.

Mancini N, Carletti S, Ghidoli N, Cichero P, Burioni R, Clement M. The Era of Molecular and other Nonculture-based Methods in Diagnosis of Sepsis. Clin Microbiol Rev 2010; 23:235-51.

Martiny D, Debaugnies F, Gateff D, Gerard M, Aoun M, Martin C, Konopmiki D. Impact of Rapid Microbial Identification Directly from Positive Blood Cultures using Matrixassisted Laser Desorption/ionization Time-of-flight Mass Spectrometry on Patient Management. Clin Microbiol Infect 2013;19:E568-81

Maude RR, de Jongm HK, Wijedoru L, Fukushima M, Ghose A, Samad R. The Diagnostic Accuracy of Three Rapid Diagnostic tests for Typhoid Fever at Chittagong Medical College Hospital, Chittagong, Bandladesh. Tropl Med Int Health 2015; 20(10):1376-84.

Mawazo A, Bwire GM, Matee MIN. Performance of Widal test and Stool Culture in the Diagnosis of Typhoid Fever among Suspected Patients in Dares Salaam, Tanzania, BMC Research Notes 2019;12(1):316.

Mawazo A, George M. B, and Mecky I. N. M. Performance of Widal test and stool culture in the diagnosis of typhoid fever among suspected patients in Dar es Salaam, Tanzania BMC Res Notes 2019 BMC Res Note 12; 316

McKinnon LR, Abdool KQ. Honing in on Enteric Fever. eLife 2014;3,e03545

Mehmood K, Sundus A, Naqvi IH, Ibrahim MF, Siddique O, Ibrahim NF. Typhidot A Blessing or a Menace. Pakistan J Med Sc 2015;31(2):439. 
Mejias A, Dimo B, Suarez NM, et al. Whole blood gene expression profiles to assess pathogenesis and disease severity in infants with respiratory syncytial virus infection. PLoS Med 2013; 10:e1001549.

Minjibir Abdullahi A., Sani U. Diso, Idris S. Ibrahim, Muhammad S. Abdallah, Muhammad Ali. Comparative Study of Widal test Against Stool Culture in Diagnosis of Typhoid Fever Suspected Cases in Kano, Northern Nigeria. South Asian Res J Eng Tech 2020; 2:5

Mogasale V, Maskery B, Ochai RI, Lee JS, Mogasale VV, Ramani ES... \& Kim YE. Burden of Typhoid Fever in Low-income and Middle-income Countries: A Systematic, Literature based Update with Risk Factor Adjustment. Lancet Glob Health 2014;2(12):e696.

Mogasale V, Ramani E, Mogasale V V, Park J. What proportion of Salmonella Typhi cases are detected by blood culture? A systematic literature review. Ann Clin Microbiol Antimicrob. 2016; 15(1):32

Mogasale V, Ramani E, Mogasale VV, Park J. What Proportion of Salmonella typhi cases are detected by Blood Culture? A Systematic Literature Review. Annal of Clin Microbiol Antimicrob 2016;15(1):32.

Moore CE, Pan-Ngum W, Wijedoru LP, Sona S, Nga TV, Duy PT, Vinh PV, Chheng K. Evaluation of the Diagnostic Accuracy of Typhoid IgM Flow Assay for the Diagnosis of Typhoid Fever in Cambodian Children using a Bayesian Latent Class Model Assuming an Imperfect Gold Standard. The America J Trop Med Hyg 2014;90:114-20.

Nakaya H. I, Wrammert J, Lee E. K, et al. Systems biology of vaccination for seasonal influenza in humans. Nat Immunol 2011; 12:786-95.

Narayanappa D, Sripathi R, Jagdishkumar K, Rajani HS. Comparative Study of Dot Enzyme Immunoassay (Typhidot-M) and Widal test in the Diagnosis of Typhoid Fever, Indian Pediatr 2010;47.

Nasstrom E, Parry CM, Vu Thieu NT, Maude RR, de Jong HK, Fukushima M, Rzhepishevska O. Reproducible Diagnostic Metabolites in Plasma from Typhoid Fever Patients in Asia and Africa. 2017; dio:10.7554/eLife.15651.

Nasstrom E, Thieu NTV, Dongol S, Karkey A, Vinh PV, Thanh TH, Basnyat B. Salmonella Typhi and Salmonella Paratyphi A Elaborate Distinct Systemic Metabolite Signatures during Enteric Fever. eLife 2014;3:e03100.

Nga T.V, Karkey A, Dongol S, et al.. The sensitivity of real-time PCR amplification targeting invasive Salmonella serovars in biological specimens. BMC Infect Dis, 2010; 10:125.

Ohanu M E, Michael O. I, Uzoamaka M, Obinna D. O, Harish C. G. Typhoid fever among febrile Nigerian patients: Prevalence, diagnostic performance of the Widal test and antibiotic multi-drug resistance. Malawi Medical Journal 2019; 31 (3): 184-192

Olsen SJ, Pruckler J, Bibb W, Nguyen T M, Tran MT, Nguyen TM, Sivapalasingam S. Evaluation of Rapid Diagnostic tests for Typhoid Fever. $J$ Clin Microbiol 2004;42(5):1885-9.

Paolucci M, Landini MP, Sambri V. Conventional and Molecular Techniques for the Early Diagnosis of Bacteraemia. Int J Antimicrob Agents 2010; 36: S6-6.

Park K S, Hyun J C, Farhana K, Hakho L, Rasheduzzaman R, Md. Taufiqur B, Amanda B, Jason B. H, Stephen B. C, Edward T. R, Firdausi Q, Ralph W \& Richelle C. C. AmagnetoDNA nanoparticle system for the rapid and sensitive diagnosis of enteric fever. Scientific Reports 2016; 6:32878 
Parry CM, Wijedoru L, Arjyal A, Baker S. The Utility of Diagnostic tests for Enteric Fever in Endemic Locations. Expert Rev anti- Infective Ther 2011;9(6):711-25.

Patel RP, Trivedi MB. Study of Diagnostic Efficacy of Widal Slide Agglutination test against Widal tube Agglutination test in Enteric Fever. Indian J Microbiol Research 2017;4(3):2679.

Prasad KL, Oberoi JK, Goel N, Wattal C. Comparative Evaluation of Two Rapid SalmonellaIgM tests and Blood Culture in the Diagnosis of Enteric Fever. Indian J Med Microbiol 2015;33(2):237-42.

Ramyi MS, Ihuoma OJ, Ogundeko TO, Ameh JM, Olorundare F, Adeniyi OG, Izam MM. Comparative Study on the use of Widal test and Stool Culture in the Laboratory Diagnosis of Salmonella Infection in Adult and Children in Jos Metropolis, Plateau State, Nigeria. Int J Sc Research 2013;2319-7064.

Raqib R, Rahman J, Kamaluddin A.K.M, Kamal S.M.M, Banu, F.A, Ahmed S, Rahim Z, Bardhan P.K, Andersson J, Sack D.A. Rapid diagnosis of active tuberculosis by detecting antibodies from lymphocyte secretions. J. Infect. Dis, 2003; 188, 364-370.

Salama R1, Said NM. A Comparative Study of the Typhidot (Dot-EIA) versus Widal test in Diagnosis of Typhoid Fever among Egyptian Patients. Open J Gastroenterology 2019;9:91-8.

Sandro C. Typhoid Intestinal Perforation in Developing Countries: Still Unavoidable Deaths? World J Gastroent 2017;23(11):1925-31.

Sharma T, Bhatnagar S, Tiwari A. Typhoid Diagnostics: Looking Beneath the Surface. J Clin Diagnost research. 2018;12(9): KE01-7.

Sheikh A, Bhuiyan, M.S, Khanam F, Chowdhury F, Saha A, Ahmed D, Jamil K.M.A, LaRocque R.C, Harris J.B, Ahmad M.M, et al. Salmonella enterica serovar Typhispecific immunoglobulin A antibody responses in plasma and antibody in lymphocyte supernatant specimens in Bangladeshi patients with suspected typhoid fever. Clin. Vaccine Immunol, 2009; 16, 1587-1594.

Sherwal BL, Dhamija RK, Randhawa VS, Jais M, Kaintura A, Kumar M. A Comparative Study of Typhidot and Widal test in Patients of Typhoid Fever, J Indian Academy of Clin Med 2004;5(3):246.

Shrinet J, Shastri JS, Gaind R, Bhavesh NS, Sunil S. Serum metabolomics analysis of patients with chikungunya and dengue mono/co-infections reveals distinct metabolite signatures in the three disease conditions. Sci Rep 2016; 6:36833.

Siba V, Horwood PF, Vanuga K, Wapling J, Sehuko R, Siba PM, Greenhill AR. Evaluation of Serological Diagnostic tests for Typhoid Fever in Papua New Guinea using a Composite Reference Standard. Clin Vaccine Immunol 2012;1833-7.

Stanaway JD, Reiner RC, Blacker BF, Goldberg EM, Khalil IA, Troeger CE, Andrews JR, Bhutta ZA, Crump JA, Im J, Marks F. The global burden of typhoid and paratyphoid fevers: a systemic analysis for the global burden burden of disease study group 2017. Lancet Infect Dis 2019;19(4):369-81.

Storey HL, Huang Y, Crudder C, Golden A, de los Santos T, Hawkins K. A Meta-Analysis of Typhoid Diagnostic Accuracy Studies: A Recommendation to Adopt a Standardized Composite Reference. PLoS One 2015; 10(11):e0142364.

Subramaniam K.S, Spaulding E, Ivan E, et al. The T-cell inhibitory molecule butyrophilinlike 2 is up-regulated in mild Plasmodium falciparum infection and is protective during experimental cerebral malaria. J Infect Dis 2015; 212:1322-31. 
Tarupiwa A, Tapera S, Mtapuri-Zinyowera S, Gumbo P, Ruhanya V, Gudza-Mugabe M, Majuru NX, Chn'ombe N. Evaluation of TUBEX-TF and ONSITE Typhoid IgG/IgM Combo Rapid tests to detect Salmonella enterica serovar Typhi Infection during a Typhoid Outbreak in Harare, Zimbabwe, BMC Research Notes 2015;8(1):50.test. Amer J Bioch 2012;2(1):16-8.

Thriemer K, Ley B, Menten J, Jacobs J, van den Ende JA. A Systematic Review and Metaanalysis of the Performance of Two Point of care Typhoid Fever tests. TUBEX TF and Typhidot, in Endemic Countries. PLOS ONE 2013;8(12):e81263.

Ugochukwu I, Amu OC, Nzegwu MA. Ileal Perforation due to Typhoid Fever-Review of Operative Management and Outcome in an Urban Centre in Nigeria. Int $J$ Surg 2013;11(3):218-22.

Vahey M.T, Wang Z, Kester K.E, et al. Expression of genes associated with immunoproteasome processing of major histocompatibility complex peptides is indicative of protection with adjuvanted RTS,S malaria vaccine. J Infect Dis; 2010; 201:580-9.

Vallenas C, Hernandez H, Kay B, Black R, Gotuzzo E. Efficacy of Bone Marrow, Blood, Stool and Duodenal Contents Cultures for Bacteriologic Confirmation of Typhoid Fever in Children. Pediat Infect Dis 1985;4:496-8.

Wam EC, Arrey CN, Sama LF, Agyingi LA, Wam AN. Comparative Study on the use of Widal test to Stool Culture in the Laboratory Diagnosis of Typhoid Fever in Holy Family Hospital Akum, North West Region of Cameroon. The Open Microbiol J 2019; 13:73-80

Weiner J 3rd, Maertzdorf J, Sutherland JS, et al. GC6-74 Consortium. Metabolite changes in blood predict the onset of tuberculosis. Nat Commun 2018; 9:5208.

Whiting P F, Rutjes A W, Westwood M E, Mallett S. A systematic review classifies sources of bias and variation in diagnostic test accuracy studies. J Clin Epidemiol 2013; 66:1093-1104.

WHO. 2015. Immunization, Vaccines and Biological Typhoid. World Heal Organ 1-2 Wijedoru L, Mallett S, Parry CM. Rapid Diagnostic tests for Typhoid and Paratyphoid (Enteric) Fever. Cochrane Databases System Reviews, 2017; https://oi.org/10.1002/14651858.

Wlekidan LN, Gebremarian SA, Welderufael AL, Muthupandian S, Haile TD, Dejene TA. Diagnosis and Treatment of Typhiod Fever and Associated Prevailing Drug Resistance in Northern Ethiopia. Intl J Infect Dis 2015;35:96-102.

World Health Organisation, WHO. The Diagnosis, Treatment, and Prevention of Typhoid Fever. 2003

World Health Organization. Typhoid vaccines: WHO Position Paper. March, 2018 Recommendation Vaccine 2019;37(2): 214-6.

Zaki SA, Karande S. Multidrug-resistance Typhoid Fever: A Review. The J Infection Develop Count 2011;5(5):324-37.

Zhou L, Jones C, Gibani M. M, et al. Development and evaluation of a blood culture PCR assay for rapid detection of Salmonella Paratyphi A in clinical samples. PLoS One 2016; 11:e0150576.

Zhou L, Pollard A. J. A novel method of selective removal of human DNA improves $\quad$ PCR sensitivity for detection of Salmonella Typhi in blood samples. BMC Infect Dis 2012; 12:164.

Zurfluh S, Baumgartner T, Meier MA, et al. The role of metabolomic markers for patients with infectious diseases: implications for risk stratification and therapeutic modulation. Expert Rev Anti Infect Ther 2018; 16:133-42. 